\title{
Modification of factor VIII complex properties in patients with liver disease
}

\author{
P. MAISONNEUVE AND YVETTE SULTAN
}

From the Laboratoire d'Hémostase, Institut de Recherches sur les Maladies du Sang, Hopital St Louis, 2, place du Dr. Fournier 75475, Paris Cedex 10

SUMMARY Factor VIII procoagulant activity (VIII:C), factor VIII related antigen (VIIIR:AG), and the von Willebrand factor (VIIIR:WF) were measured in 19 patients with liver disease (8 cases of alcoholic cirrhosis and 11 with acute viral hepatitis). In both groups of patients the levels of VIII:C, VIIIR:AG, and VIIIR:WF were above normal or normal with mean values well above the normal range. VIIIR:AG was also measured in the same patients by two-dimensional electrophoresis, and its biological properties were measured after purification by chromatography. By both methods the VIIIR:AG in the patients with liver disease differed from normal VIIIR:AG. In five of the patients with acute viral hepatitis, who were tested after they had recovered, the previously elevated levels of VIII:C, VIIIR:AG, and VIIIR:WF had dropped to normal limits and the qualitative abnormalities had disappeared.

Haemostatic defects in liver disease may be associated with a decrease in coagulation factors (Rapaport et al., 1960), an increase in fibrinolytic activity (Fletcher et al., 1964), thrombocytopenia (Ratnoff $e t$ al., 1950), and qualitative platelet defects (Breddin, 1962). Evidence of disseminated intravascular coagulation (DIC) was first reported in patients with cirrhosis of the liver by Bergström et al. (1960). In contrast to these findings, an increase in the level of factor VIII procoagulant activity (VIII:C) has been reported in cirrhosis of the liver (Zetterquist and von Francken, 1963; Van Outryve et al., 1973) and in fulminant hepatitis (Meili and Straub, 1970; Böhmig et al., 1971). Using rabbit antiserum to purified factor VIII, Green and Ratnoff (1974) demonstrated a similar increase in the factor VIII related antigen (VIIIR:AG). The present study was carried out in order to assess the functional activities of VIIIR:AG in alcoholic cirrhosis of the liver and in viral hepatitis.

\section{Patients and controls}

Eleven patients with viral hepatitis were studied during the acute phase of the disease. In all cases, the serum alanine aminotransferase (SGPT) was increased with a mean value of 430 (normal range

Received for publication 12 July 1976
5-20) units. Six patients were positive for hepatitis B antigen (HB Ag). Five patients were tested more than one year after recovery. At that time the SGPT levels were all normal, with a mean value of 9 units, and the HBAg tests were all negative.

Eight patients with alcoholic cirrhosis were also studied. Diagnosis was made by clinical data and liver function tests; in five cases it was confirmed by liver biopsy. Five patients, in whom the cirrhosis had become decompensated, died within six months.

Control plasmas were obtained from 20 healthy volunteers without liver disease or history of bleeding tendency. The VIIIR:AG was estimated on each sample. The remaining plasma was pooled, stored at $-70^{\circ} \mathrm{C}$, and used as a standard for assays of VIII:C, VIIIR:AG, and the von Willebrand factor (VIIIR:WF).

\section{Methods}

Blood for coagulation and immunological studies was collected into $3.8 \%$ trisodium citrate (1 part of anticoagulant to 9 parts of blood). In eight cases a duplicate specimen was taken into $3.8 \%$ trisodium citrate + Kunitz inhibitor (10 $000 \mathrm{U} / \mathrm{ml}$ of Iniprol). Hard spun platelet-poor plasma was obtained by centrifugation at $1000 \mathrm{~g}$ for 10 minutes at $12^{\circ} \mathrm{C}$.

The prothrombin time was carried out by the method of Quick, and one-stage assays for factors 
II, V, VII, and X were performed on plasma artificially depleted of these factors.

Fibrinogen was determined by the weight of dried protein.

VIII:C was assayed on fresh blood by the onestage assay of Soulier and Larrieu (1953) using the plasma of a severe haemophiliac as substrate (mean value $98 \cdot 2 \% \pm 31 \cdot 77(1 \mathrm{SD})$ ).

VIIIR:WF was determined by the ristocetininduced platelet aggregation assay using suspensions of normal washed platelets in different dilutions of test plasma (Weiss et al., 1973a) modified by Sultan et al. (1975a) (mean value $102 \cdot 88 \% \pm 32 \cdot 80$ (1 SD)).

\section{IMMUNOLOGICAL STUDIES}

These were performed on frozen plasma samples. The antisera were obtained from rabbits immunised with purified FVIII by the method of Marchesi $e t$ al. (1972).

VIIIR:AG was determined by the electroimmunoassay technique of Laurell (1966) standardised for VIIIR:AG by Sultan et al. (1975a). The mean value from 20 normal plasmas was $94 \cdot 34 \% \pm 29 \cdot 81$ (1 SD).

Crossed immunoelectrophoresis was performed by the technique of Laurell (1965) modified by Sultan et al. (1976). Under standard conditions the peak of precipitation obtained is not symmetrical, but the maximum height is usually on the cathodal part of the peak and correlates with slow moving subfractions. Limits of migration were established in the plasma of 10 normal subjects: the distance from the well to the beginning of the peak was $6 \pm 1.2 \mathrm{~mm}$, and the distance from the well to the end of the peak was $27.9 \pm 2.4 \mathrm{~mm}$. The electrophoretic pattern of migration of VIIIR:AG in normal plasma indicates that this is a heterogeneous molecule composed of several subfractions with different electrophoretic mobilities (Fig. 1a).

\section{ISOLATION OF FVIII ON A SEPHAROSE 4B \\ COLUMN}

Six millilitres of cryoprecipitate obtained from $40 \mathrm{ml}$ of plasma were placed on a column after stepwise digestion by $\alpha$ chymotrypsin (Marchesi et al., 1972). A $2.5 \times 45 \mathrm{~cm}$ column (Pharmacia, Sweden) packed with Sepharose 4B in TRIS $\mathrm{NaCl}$ buffer pH $7 \cdot 4$ at $4^{\circ} \mathrm{C}$ was used.

Two-millilitre samples were collected and tested for protein concentration and VIII:C activity immediately after elution. Those aliquots which contained VIII:C were pooled in $6 \mathrm{ml}$ fractions and concentrated to $1 \mathrm{ml}$ by dialysis against Ficoll and tested for VIIIR:AG and VIIIR:WF.

The value of the three parameters was calculated for every fraction as well as the ratios VIIIR:AG/ VIIIR:WF and VIIIR:AG/VIII:C. In normal plasma, the former ratio was arbitrarily taken to be 1 . After the filtration of normal cryoprecipitate the FVIII complex is eluted in the void volume (from

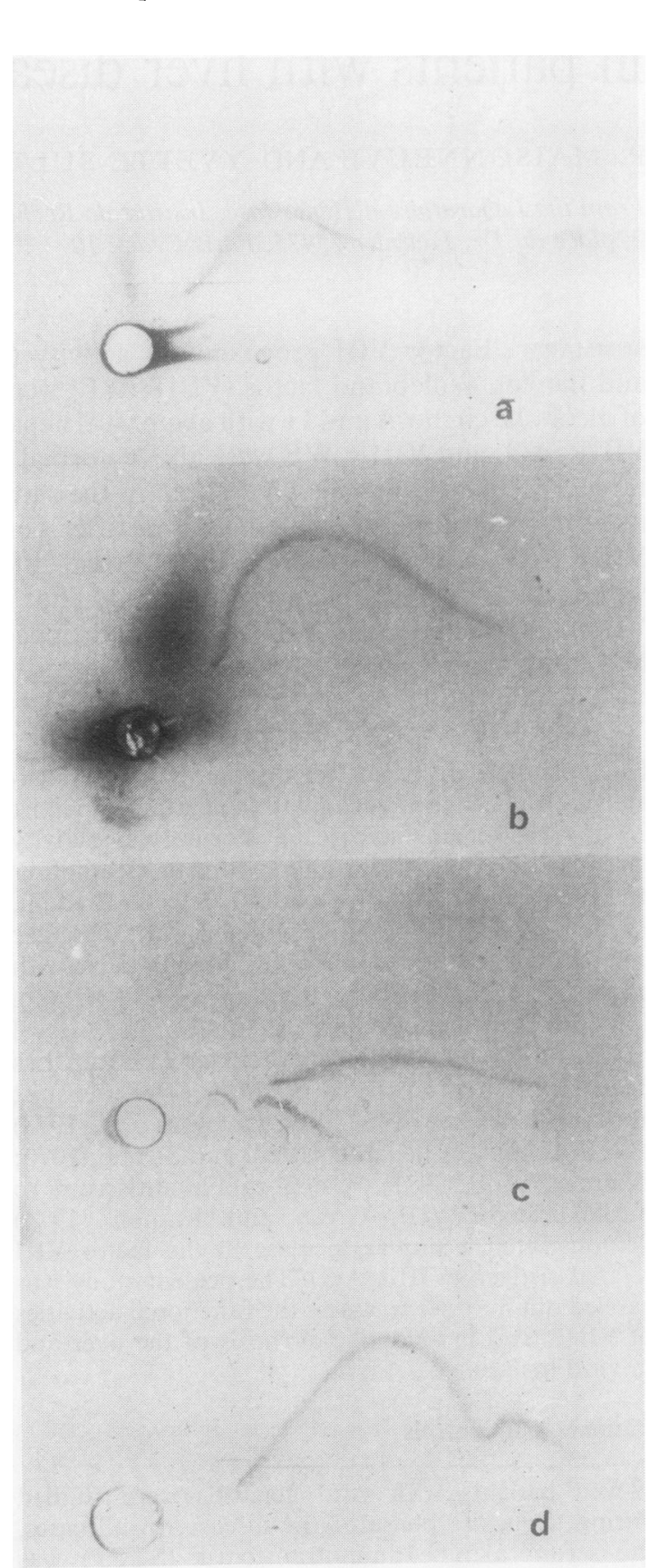

Fig. 1 Crossed immunoelectrophoresis performed on the plasma of $(a)$ a normal control, (b and d) viral hepatitis, (c) alcoholic cirrhosis. 
30 to $70 \mathrm{ml}$ ) isolated from the other proteins (Fig. 3a). VIIIR:AG and VIIIR:WF activity is found in the same fractions as VIII:C. The ratio between VIIIR: AG/VIIIR:WF is $2 / 3$ at the maximum point of VIIIR:AG elution and 1 at the end of the elution (Table 5).

\section{Results}

The levels of VIII:C, VIIIR:AG, and VIIIR:WF are shown in Figure 2.

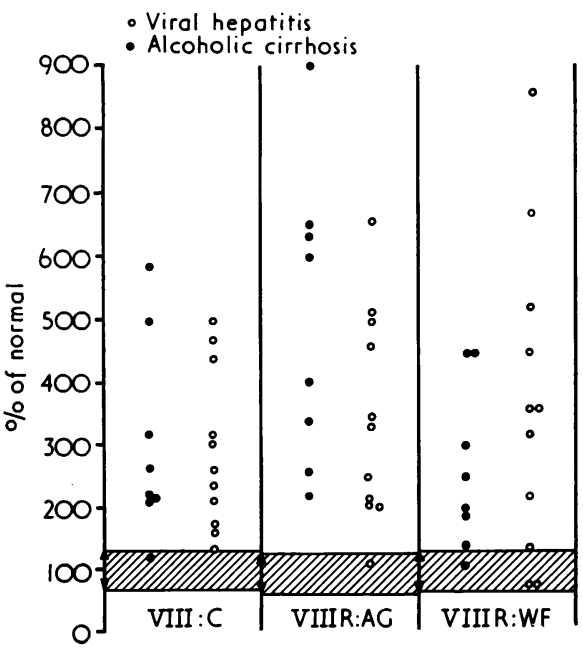

Fig. 2 VIII:C, VIIIR:AG, and VIIIR:WF of patients with viral hepatitis and alcoholic cirrhosis.

VIII:C was above the normal range in seven out of eight cases of cirrhosis and normal in one; it was above normal in all 11 cases of viral hepatitis. The VIII:C range was $117 \%$ to $585 \%$ with a mean value of $301 \cdot 2 \%$ (Table 1 ).

VIIIR:AG was increased above the normal range in all patients with cirrhosis; it was also above

Table 1 Mean value of VIII:C, VIIIR,WF and VIIIR:AG in patients with alcoholic cirrhosis and hepatitis

\begin{tabular}{|c|c|c|c|}
\hline Patient Group & $V I I I: C \%$ & $\begin{array}{l}\text { VIIIR: } W F \\
\%\end{array}$ & $\begin{array}{l}\text { VIIIR:AG } \\
\%\end{array}$ \\
\hline $\begin{array}{l}\text { Liver disease } \\
\text { Mean } \\
\text { Viral hepatitis (11) } \\
\text { Mean } \\
\text { Range }\end{array}$ & $\begin{array}{l}301 \cdot 2 \\
302 \\
298 \cdot 5 \\
(135-500)\end{array}$ & $\begin{array}{l}302 \cdot 4 \\
367 \cdot 5 \\
344 \cdot 9 \\
(74-860)\end{array}$ & $\begin{array}{l}410 \cdot 7 \\
341 \cdot 36 \\
309 \\
(110-655)\end{array}$ \\
\hline $\begin{array}{l}\text { Alcoholic cirrhosis (8) } \\
\text { Mean } \\
\text { Range } \\
\text { Controls }\end{array}$ & $\begin{array}{l}304 \\
(117-585) \\
98 \cdot 2 \\
\pm 31 \cdot 77 \mathrm{SD}\end{array}$ & $\begin{array}{l}260 \\
(110-450) \\
102 \cdot 88 \\
\pm 32 \cdot 80 \mathrm{SD}\end{array}$ & $\begin{array}{l}512 \cdot 5 \\
(220-900) \\
94 \cdot 34 \\
\pm 29 \cdot 81 \mathrm{SD}\end{array}$ \\
\hline
\end{tabular}

normal in 10 patients with viral hepatitis and normal in one. The VIIIR:AG range was $110 \%$ to $655 \%$ with a mean value of $410 \cdot 7 \%$ (Table 1 ).

VIIIR:WF was above the normal range in seven out of eight cirrhotics and normal in one; it was above normal in nine out of 11 patients with viral hepatitis and normal in two. The VIIIR:WF range was $74 \%$ to $860 \%$ with a mean value of $302.9 \%$ (Table 1).

In cirrhotic patients, there was no correlation between these three parameters in any given patient (Table 2). High levels of VIIIR:AG were not followed by a proportional increase in VIIIR:WF or VIII:C in any of the cases studied. The ratio of the mean value of VIIIR:AG/VIII:C was 1.6 and of VIIIR:AG/ VIIIR:WF was 2.

Table 2 VIII:C, VIIIR:WF, and VIIIR:AG in patients with alcoholic cirrhosis

\begin{tabular}{llll}
\hline Patient & VIII:C \% & VIIIR:WF \% & VIIIR:AG \% \\
\hline MJ & 500 & 300 & 900 \\
DM & 320 & 140 & 400 \\
DB & 210 & 200 & 650 \\
CR & 585 & 450 & 600 \\
SA & 220 & 450 & 440 \\
SM & 117 & 180 & 260 \\
ZA & 265 & 110 & 220 \\
FF & 215 & 250 & 630 \\
Control & $98.2 \pm 31.77$ & $102.88 \pm 32.80$ & $94.34 \pm 29.81$ \\
\hline
\end{tabular}

In the patients with viral hepatitis (Table 3 ) the results of the ratios were less clear cut. In seven cases out of the 11 studied, the ratio followed the same pattern as in patients with cirrhosis; three cases showed a discrepancy due to high levels of VIIIR:WF and lower levels of VIIIR:AG. In two cases, very high levels of VIII:C were associated with very high levels of VIIIR:AG and lower levels of VIIIR:WF activity.

FVIII LEVELS AND LIVER FUNCTION TESTS

In viral hepatitis no apparent relationship was found between the levels of any of the FVIII

Table 3 VIII:C, VIIIR:WF, and VIIIR:AG in patients with viral hepatitis at the acute phase of the disease

\begin{tabular}{llll}
\hline Patient & VIII:C \% & VIIIR:WF \% & VIIIR:AG \% \\
\hline SJ & 440 & 360 & 455 \\
SC & 235 & 670 & 330 \\
PR & 320 & 135 & 500 \\
WM & 135 & 84 & 110 \\
PM & 172 & 74 & 195 \\
FD & 470 & 360 & 510 \\
GM & 360 & 860 & 655 \\
AR & 155 & 520 & 210 \\
NM & 211 & 220 & 200 \\
B & 325 & 320 & 340 \\
AL & 500 & 440 & 250 \\
Control & $98 \cdot 2 \pm 31 \cdot 77$ & $102 \cdot 88 \pm 32 \cdot 80$ & $94 \cdot 34 \pm 29 \cdot 81$ \\
\hline
\end{tabular}


parameters measured and the level of SGPT or the presence of HBAg.

In alcoholic cirrhosis no apparent relation was found between the increase of the different parameters, the chronicity of the disease, and the hepatocellular damage (measured by albumin level, $\gamma$ globulins, SGPT, and bilirubin level). As would be expected, however, there was a relation between the liver cell damage and the decreased level of other clotting factors (II, VII, X, and fibrinogen).

Tests performed on blood samples collected in the presence of Kunitz inhibitor gave similar results to those performed without this enzyme inhibitor.

Crossed immunoelectrophoresis of VIIIR:AG showed a pattern obtained from patient's plasma which was abnormal by comparison with that of normal plasma (Fig. 1a).

In cases 1 (viral hepatitis) and 2 (alcoholic cirrhosis), one part of the molecule spread more than normally and showed increased electrophoretic mobility, suggesting a more heterogeneous protein with faster subfractions (Fig. 1b and c). In case 1 the distance between the well and the beginning of the peak is in the normal range, but the base of the peak is larger (Table 4). In case 2 , the peak began very far from the well (Table 4). In case 3 (viral hepatitis), two peaks were identified, suggesting the existence of two major populations of protein with different electrophoretic mobility (Fig. 1d). Distances of migration are shown in Table 4. No difference was found between patterns obtained with plasma collected on citrate alone or on citrate + Kunitz inhibitor.

Table 4 Distances of migration of FVIII protein in double-dimensional electrophoresis

\begin{tabular}{llll}
\hline Case & $d_{0}-d_{1}(\mathrm{~mm})$ & $d_{0}-d_{2}(\mathrm{~mm})$ & $d_{1}-d_{2}(\mathrm{~mm})$ \\
\hline 1 & 8 & 36 & 29 \\
2 & 19 & 35 & 16 \\
3 & 17 & 53 & 36 \\
Mean & $6 \cdot 0 \pm 1 \cdot 2$ & $27 \cdot 9 \pm 2 \cdot 4$ & $22 \cdot 1 \pm 2 \cdot 2$ \\
(10 controls) & $(1 \mathrm{SD})$ & $(1 \mathrm{SD})$ & $(1 \mathrm{SD})$ \\
\hline
\end{tabular}

ISOLATION OF PURIFIED FVIII ON A

SEPHAROSE 4B COLUMN

Although the VIIIR:AG prepared from cryoprecipitate from either group of patients eluted at the same position as VIIIR:AG prepared from normal cryoprecipitate under the same conditions, the properties were different.

Figure $3 \mathrm{~b}$ shows an example of the elution pattern of cryoprecipitate obtained from the plasma of a patient with viral hepatitis (PR, Table 3), in whom a high level of VIIIR:AG and lower VIIIR:WF and VIII:C were found. The VIIIR:AG was eluted in the void volume (26 to $58 \mathrm{ml}$ ) and separated from the other proteins. Although the trend of VIIIR:AG
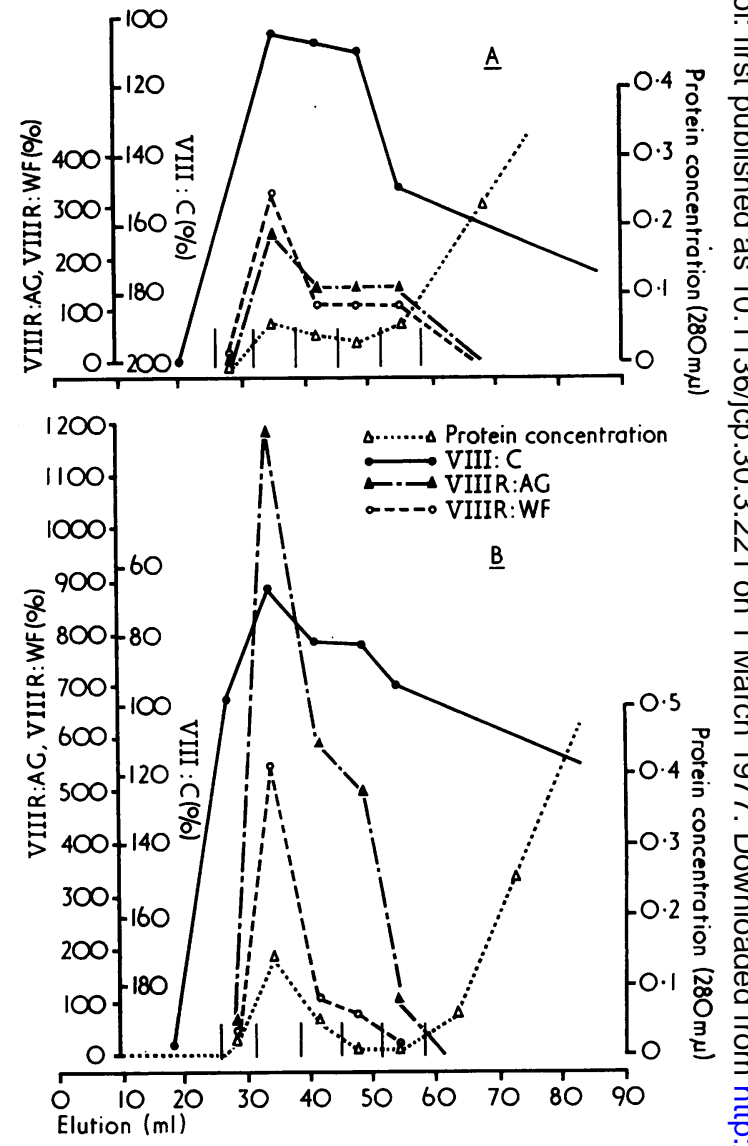

Fig. 3 (a) Elution pattern of normal cryoprecipitate on Sepharose $4 B$ column: (b) elution pattern of cryoprecipitate from the plasma of a patient with viral hepatitis.

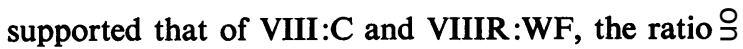
differed from normal. When the maximum amount of $D$ antigenic material had been eluted, the ratio between VIIIR:AG/VIIIR:WF was 2 and approximated to $N$ 6 at the end of the elution (Table 5). Similar results were obtained in two other patients with viral $\mathcal{N}$ hepatitis and in one with cirrhosis of the liver whow were examined by these techniques.

FVIII IN VIRAL HEPATITIS AFTER

RECOVERY

Five patients with viral hepatitis were studied more ${ }^{\top}$ than one year after liver function tests had returned $\frac{P}{\mathbb{D}}$ to normal. Table 6 shows that, except for one patient $\stackrel{\odot}{\stackrel{P}{\mathscr{C}}}$ who showed a very low activity of VIIIR:WF after $\stackrel{\unrhd}{\varrho}$ recovery, the three tested activities of the FVIII complex had returned to normal. 
Table 5 VIII:C, VIIIR:AG, and VIIIR:WF eluted from the column of Sepharose 4B from normal cryoprecipitate from the plasma of a patient with viral hepatitis

\begin{tabular}{|c|c|c|c|c|c|c|c|c|}
\hline & \multicolumn{2}{|c|}{$\begin{array}{l}\text { VIII:C } \\
\%\end{array}$} & \multicolumn{2}{|c|}{$\begin{array}{l}\text { VIIIR:WF } \\
\%\end{array}$} & \multicolumn{2}{|c|}{$\begin{array}{l}\text { VIIIR:AG } \\
\%\end{array}$} & \multicolumn{2}{|c|}{$\begin{array}{c}\text { Ratio } \\
\%\end{array} \frac{\text { VIIIR: } A G}{\text { VIIIR:WF }}$} \\
\hline & $A H$ & $N P$ & $A H$ & $N P$ & $A H$ & $N P$ & $A H$ & $N P$ \\
\hline Cryoprecipitate & 300 & 500 & 800 & 500 & 1900 & 600 & & \\
\hline $\begin{array}{l}\text { Fractions collected in seconds } \\
\text { From } 26-32 \mathrm{ml} \\
32-39 \\
39-45 \\
45-51 \\
51-58\end{array}$ & $\begin{array}{l}97 \\
67 \\
77 \\
78 \\
90\end{array}$ & $\begin{array}{l}105 \\
108 \\
110 \\
150\end{array}$ & $\begin{array}{r}36 \\
550 \\
110 \\
70 \\
19\end{array}$ & $\begin{array}{r}0 \\
320 \\
110 \\
110 \\
110\end{array}$ & $\begin{array}{r}49 \\
1250 \\
600 \\
450 \\
100\end{array}$ & $\begin{array}{r}0 \\
230 \\
145 \\
145 \\
145\end{array}$ & $\begin{array}{l}2 / 1 \\
5 / 1 \\
6 / 1 \\
6 / 1\end{array}$ & $\begin{array}{l}2 / 3 \\
1 / 1 \\
1 / 1 \\
1 / 1\end{array}$ \\
\hline
\end{tabular}

AH = acute hepatitis; NP $=$ normal plasma

Table 6 Factor VIII levels in viral hepatitis at the acute phase of the disease and after recovery

\begin{tabular}{|c|c|c|c|}
\hline & $\begin{array}{l}\text { VIII:C \% } \\
\text { (mean value) }\end{array}$ & $\begin{array}{l}\text { VIIIR: WF \% } \\
\text { (mean value) }\end{array}$ & $\begin{array}{l}\text { VIIIR:AG \% } \\
\text { (mean value) }\end{array}$ \\
\hline $\begin{array}{l}\text { At the acute } \\
\text { phase } \\
\text { (11 cases) } \\
\text { After }\end{array}$ & $\begin{array}{l}280 \cdot 77 \\
(135-470)\end{array}$ & $\begin{array}{l}335 \\
(60-670)\end{array}$ & $\begin{array}{l}323 \cdot 61 \\
(110-655)\end{array}$ \\
\hline $\begin{array}{l}\text { recovery } \\
\quad(5 \text { cases) }\end{array}$ & $\begin{array}{l}92 \cdot 5 \\
(66-115)\end{array}$ & $\begin{array}{c}50 \cdot 7 \\
(6 \cdot 5-90)\end{array}$ & $\begin{array}{c}62 \cdot 6 \\
(45-83)\end{array}$ \\
\hline
\end{tabular}

The evolution of the electrophoretic mobility of VIIIR:AG in a case of viral hepatitis is shown in Figure 4.

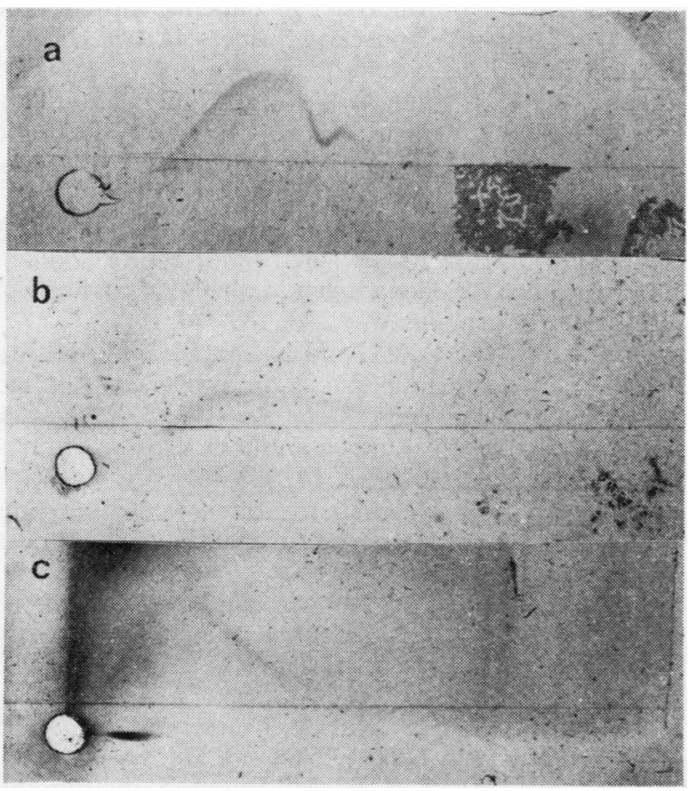

Fig. 4 Crossed immunoelectrophoresis performed on the plasma of a patient with viral hepatitis (a) at the onset of the disease, (b) six months later, and (c) after recovery.
Crossed electrophoresis was carried out at the onset of the disease, and six months later, when liver function tests were again normal. At this time, although the VIIIR:AG levels were in the normal range, the pattern of crossed electrophoresis was still abnormal. Two years after recovery the pattern was identical with that of VIIIR:AG in normal plasma.

\section{Discussion}

This study of FVIII in patients with liver diseases has confirmed that there is an associated rise of VIII:C and VIIIR:AG in the plasma of patients with viral hepatitis and alcoholic cirrhosis of the liver. Furthermore, it was shown that this is associated with an increase in VIIIR:WF activity as demonstrated by the ability of the protein to induce ristocetin aggregation in a washed platelet suspension. The fact that in most of the cases the increase in VIIIR:WF was less than the increase in VIII:C and VIIIR:AG suggests a functionally different molecule from that found in normal plasma. The present results suggested a functional discrepancy between FVIII in patients with liver disease and FVIII in the plasma of normal subjects.

As in the plasma of haemophiliacs with viral hepatitis (Sultan et al., 1976), our study suggests that the properties of the increased circulating FVIII which is found in patients with liver disease are abnormal throughout the duration of the condition.

In normal plasma, there is a constant correlation between the level of VIIIR:AG and its biological activities (Weiss et al., 1973b). In all the patients studied, a dissociation between the parameters was constantly found. In most of the cases the antigenic material has less VIIIR:WF and VIII:C activity. In some cases of viral hepatitis, the opposite was found and the antigenic material was more active in inducing ristocetin platelet aggregation.

In the cases in which there was more VIIIR:WF 
than VIIIR:AG, no relationship with the liver function tests or with the aetiology of the disease could be established.

The pattern obtained in crossed antigen antibody electrophoresis suggested a more heterogeneous molecule with an increase in the subfractions with more anodal electrophoretic mobility. The elution pattern of cryoprecipitate on a Sepharose 4B column showed that purified VIIIR:AG had decreased VIIIR:WF activity.

Similar findings have been reported in patients with genetic variants of von Willebrand's disease, in whom the level of VIIIR:AG had been in the normal range (Gralnick et al., 1975) or lower than normal (Sultan et al., 1975b) with the presence of a non-functional protein. In viral hepatitis, it proved to be an acquired and transitory abnormality since, after recovery, FVIII returned to normal levels and the qualitative changes disappeared. The present study also showed that the changes in electrophoretic mobility observed in the acute phase took longer to return to normal than the tests used to evaluate liver injury such as SGPT. In this connection, it was more sensitive although non-specific.

Two hypothetical mechanisms can be proposed for the increase in this partially non-functional protein in the plasma of patients with liver diseases: the increased release of an abnormal or partially abnormal protein by the endothelial cells (Jaffe et al., 1974) of the liver or the impaired catabolism of a normally released protein with accumulation in the plasma of these patients of a partially degraded protein. Proteolysis, especially fibrinolysis, is known to be increased in such patients. However, since control tests on blood collected in the presence of a proteolytic enzyme inhibitor proved to be exactly the same as those performed on blood collected in citrate only, it can be assumed that, if we are dealing with a partially proteolysed protein, this mechanism must have occurred in vivo before the blood was collected.

It is now well established that the VIIIR:WF activity (the property of inducing platelet aggregation in the presence of ristocetin) is a property of VIIIR:AG (Bouma et al., 1972). However, in normal plasma there is a well-established proportion between functional and non-functional molecules responsible for this activity. After the elution of VIIIR:AG from normal plasma on a Sepharose 4B column the molecules eluted at the void volume have much more VIIIR:WF activity than molecules eluted later. In congenital diseases, such as von Willebrand's disease, as well as in acquired diseases such as liver disease, the proportion between functional and nonfunctional molecules seems to differ from that in normal plasma.

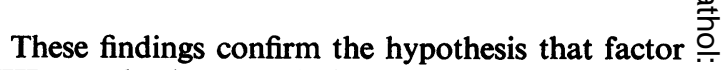
VIII complex in normal plasma is an heterogeneous $\overrightarrow{\vec{F}}$ group of molecules and pathological conditions can increase this heterogeneity.

We are very grateful to $\operatorname{Dr} K$. Dormandy for $\frac{\bar{D}}{\vec{D}}$ reviewing the manuscript and for her help in the $\unrhd$ translation into English.

\section{References}

Bergström, K., Blombäck, B., and Kleen, G. (1960). Studies on the plasma fibrinolytic activity in a case of liver cirrhosis. Acta med. scand., 168, 291-305.

Böhmig, H. J., Abouna, G. M., and Diez-Pardo, J. A. (1971). Coagulation studies in acute hepatic necrosis: $\omega$ effects on coagulation of extracorporeal liver perfusion $N$ and exchange blood transfusion. Thrombos. Diathes. haemorrh. (Stuttg.), 26, 341-352.

Bouma, B. N., Wiegerinck, Y., Sixma, J. J., Van Mourik, J. A., and Mochtar, I. A. (1972). Immunological characterization of purified anti-haemophilic factor $\mathbf{A}$ (factor VIII) which corrects abnormal platelet retention in Von Willebrand's disease. Nature, new Biol., 236, 104-106.

Breddin, K. (1962). Hämorrhagische Diathesen bei Lebererkrankungen unter besonderer Berucksichtigung der Thrombocytenfunktion. Acta haemat. (Basel), 27, 1-16.

Fletcher, A. P., Biederman. O., Moore, D., Alkjaersig, N., and Sherry, S. (1964). Abnormal plasminogen-plasmin system activity (fibrinolysis) in patients with hepatic cirrhosis; its cause and consequences. J. clin. Invest., 43, 681-695.

Gralnick, H. R., Coller, B. S., and Sultan, Y. (1975). Studies of the human Factor VIII/von Willebrand factor protein. III. Qualitative defects in Von Willebrand's disease. J. clin. Invest., 56, 814-827.

Green, A. J. and Ratnoff, O. D. (1974). Elevated antihemophilic factor (AHF, factor VIII) procoagulant activity and AHF-like antigen in alcoholic cirrhosis of the liver. J. Lab. clin. Med., 83, 189-197.

Jaffe, E. A., Hoyer, L. W., and Nachman, R. L. (1974). Synthesis of antihemophilic factor antigen by cultured human endothelial cells. J. clin. Invest., 52, 2757-2764.

Laurell, C. B. (1965). Antigen-antibody crossed electrophoresis. Analyt. Biochem., 10, 358-361.

Laurell, C. B. (1966). Quantitative estimation of proteins by electrophoresis in agarose gel containing antibodies. Analyt. Biochem., 15, 45-52.

Marchesi, S. L., Shulman, N. R., and Gralnick, H. R. O (1972). Studies on the purification and characterization 0 of human factor VIII. J. clin. Invest., 51, 2151-2161.

Meili, E. O. and Straub, P. W. (1970). Elevation of $\stackrel{D}{\rightarrow}$ factor VIII in acute fatal liver necrosis. Thrombos. Diathes. haemorrh. (Stuttg.), 24, 161-174.

Rapaport, S. I., Ames, S. B., Mikkelsen, S., and Goodman, J. R. (1960). Plasma clotting factors in chronic hepatocellular disease. New Engl.J. Med., 263, 278-282.

Ratnoff, O. D., Conley, C. L., and Berthrong, M. (1950). The differentiation between extrahepatic and intra- 
hepatic obstruction of the portal circulation. A clinical study of the "Banti syndrome". Bull. Johns Hopk. Hosp., 87, 305-327.

Soulier, J. P. and Larrieu, M. J. (1953). Nouvelle méthode de diagnostic de l'hémophilie. Dosage des facteurs antihémophiliques A et B. Sang, 24, 205-215.

Sultan, Y., Maisonneuve, P., and Simeon, J. (1976). Modifications of F. VIII RA in hemophiliacs with acute hepatitis and subclinical liver disease. Scand. $J$. Haemat., Suppl. 1976, (In press.)

Sultan, Y., Simeon, J., and Caen, J. P. (1975a). Detection of heterozygotes in both parents of homozygous patients with Von Willebrand's disease. J. clin. Path., 28, 309-316.

Sultan, Y., Simeon, J., and Caen, J. P. (1975b). Electrophoretic heterogeneity of normal factor VIII/Von Willebrand protein, and abnormal electrophoretic mobility in patients with Von Willebrand's disease. J. Lab. clin. Med., 87, 185-197.
Van Outryve, M., Baele, G., de Weerdt, G. A., and Barbier, F. (1973). Antihaemophilic factor A (F VIII) and serum fibrin-fibrinogen degradation products in hepatic cirrhosis. Scand. J. Haemat., 11, 148-152.

Weiss, H. J., Hoyer, L. W., Rickles, F. R., Varma, A., and Rogers, J. (1973b). Quantitative assay of a plasma factor deficient in Von Willebrand's disease that is necessary for platelet aggregation: relationship to factor VIII procoagulant activity and antigen content. J. clin. Invest., 52, 2708-2716.

Weiss, H. J., Rogers, J., and Brand, H. (1973a). Defective ristocetin-induced platelet aggregation in von Willebrand's disease and its correction by factor VIII. J. clin. Invest., 52, 2697-2707.

Zetterquist, E. and Von Francken, I. (1963). Coagulation disturbances with manifest bleeding in extrahepatic portal hypertension and in liver cirrhosis. Preliminary results of Heparin treatment. Acta Med. Scand., 173, 6-15. 